\title{
Point of Sale (POS) Network with Embedded Fingerprint Biometric Authentication
}

\author{
${ }^{1}$ Hussah Adnan Alzamel, ${ }^{2}$ Muneerah Alshabanah, ${ }^{2}$ Mutasem k. Alsmadi \\ ${ }^{1}$ Department of Finance, College of Applied Studies and Community Service, Imam Abdurrahman Bin Faisal \\ University, Al-Dammam, Saudi Arabia \\ 2Department of Management Information Systems, College of Applied Studies and Community Service, Imam \\ Abdurrahman Bin Faisal University, Al-Dammam, Saudi Arabia
}

\begin{abstract}
The steady growth in electronic transactions has promoted the Automated Teller Machine (ATM) thereby making it the main transaction channel for carrying out financial transactions. Conventional method of identification based on possession of ID cards or exclusive knowledge like a social security number or a password are not all together reliable. However, this has also increased the amount of fraudulent activities carried out on Automated Teller Machines (ATMs) thereby calling for efficient security mechanisms and increasing the demand for fast and accurate user identification and authentication in ATMs. In this paper, an embedded fingerprint biometric authentication scheme for Point of Sale (POS) network as additional security option to the ATM card is proposed. A fingerprint biometric technique was fused with personal identification numbers (PIN's) for authentication to upgrade the security level. The proposed idea will solve the problems that may face the customers such as theft, counterfeiting, oblivion or loss the card. Therefore, the customer will be identified once putting his finger on the reader (based on finger scanning) and the system recognizes the customer without requiring keys or cards of support. We have distributed a questioner to 586 responders, the obtained results show the importance of fingerprint biometric authentication for POS network as additional security option to the ATM card.
\end{abstract}

Keywords : POS, ATM, Fingerprint, Security, Biometric.

\section{INTRODUCTION}

The Automated Teller Machines (ATMs) provide numerous monetary services to the society and the number of users has increased tremendously due to the promotion of cashless societies by major financial institutions [1-5]. Existing ATMs are based on plastic cards with a metallic chip which is combined with a PIN (Personal Identification Number) [6]. Together this serves as a medium for logging into the banking platform of the ATM in use. The current form of authentication has withstood the taste of time but however, it has not been fail proof as previous research has shown $[7,8]$. Individuals making use of ATMs have complained of lost funds due to hackers gaining knowledge of their PINs [9] and furthermore, many individuals have also bemoaned the inability to carry out transactions due to lost or damaged debit cards thereby having to pay for a replacement. These factors have been tackled by previous researchers who propose the introduction of a biometric method of authenticating individuals and the banking community especially in developing countries with a high a level of crime and financial fraud rate. 
Biometrics can be defined as a measurable physiological and behavioral characteristic that can be captured and subsequently compared with another instance at the time of verification. It is an automated method of recognizing a person based on physiological or behavioral characteristic. It is a measure of an individual's unique physical or behavioral trait which can be used in validating or authenticating an individual. Common physical biometric characteristics include fingerprints, hand or palm geometry, retina, iris and facial scans while common behavioral characteristics are signature, handwriting, keystrokes and voice match. Biometrics technologies are a very secure way of authentication, this is due to the uniqueness of biometric data which cannot be shared, copied or lost. The authors in [10] pointed out that biometric based authentication offers several advantages over other authentication mechanisms and research has shown that the fingerprint technology in particular, can give a considerably more precise and reliable client validation.

The technological revolution influenced everything [11-46], even the methods that aim to improve the shopping and banking systems. Today, the use of Artificial Intelligence (AI) algorithms is expansive, particularly in providing solutions to challenging problems including patterns recognition and retrieval of information $[26,39,43,47-61]$, image segmentation $[11,12,22,42,62-66]$, analysis of medical images [67-71], Learning Management System [72-97], nurse rostering problem [41], Healthcare Monitoring system [25, 98], as well as prediction of river flow [40, 99, 100]. Accordingly, many systems have used the Artificial Intelligence as an effective tool for biometric authentication and using it in the transactions and banking systems [101103].
According to the tremendous technology revolution in 21st Century, many countries have begun to replace traditional tools with more modern tools. Technology is absolutely important in everyone's life. Therefore, the countries have started using technology more than it used to be, because of its direct impact on their economy, some of the problems that were faced by these countries have been solved by using technology. Also, the financial sector started to develop financial services by using the financial technology (FinTech), which is one of the most important technologies, invented to help financial institutions to increased number of customers in each institution and satisfy their desires. Henceforth, the idea of finding a secure alternative to the debit card to solve all it problems (such as; theft, card loss and fraud), by adding fingerprint to the POS machine will reduce the incidence of these Problems as well as saving time and effort.

\section{RELATED WORK}

\subsection{Mada Pay}

Mada pay is a smart mobile payment service with a special application that has the highest standards of security and encryption of private information. It allows cardholders to keep their entire bank card (both current and credit linked) in one application on smart phones. The cardholder will be able to complete the payment process for purchases up to a maximum of 100 Riyals per purchase, once the smart phone is passed after opening the lock of the phone using the secret code, On the POS device supported by the service. There is no limit to the cards that can be saved in the Pay application, and the same card can be saved on more than one device. Pay Range is widely accepted within and outside the kingdom for millions of stores that support NFCs based on National Payment system in line with international 
networks supported by the card used. What is known as the near-communication technique is the abbreviation of Near Field Communication (NFC) Is a 13.56 $\mathrm{MHz}$ wireless communication technology that can transmit data at a maximum speed of $474 \mathrm{kbps}$ and is different from being able to exchange data in a very narrow range not exceeding 4 centimeters between the two ends of the exchange of information (phone, receiver or other phone). Use of financial transactions is possible because it is so secure that it cannot be remotely dealt with remotely [104].

\subsection{POS devices (mPOS)}

This service enables you to pay your purchases from any trade shows available at this point (POS) using ATM cards and credit cards (Visa, Mastercard and American). Express). The POS network transfers the amount of your purchases from the card account to the merchant account as these accounts are within the scope of the Saudi Payment Network, the GCC network, MasterCard, Visa and American Express. The POS device allows the merchant to accept all types of bank cards (Mada, MasterCard, Visa and American Express cards). It is the ideal payment option for cardholders rather than cash, and is the most convenient payment solution for mobile business owners. The device will be linked to the merchant account at the bank to settle the amounts of transactions quickly, easily and safely, with the possibility of the trader to report the transactions executed through the device and the total amounts settled through the Internet banking companies and institutions (Flex Business) [105].

\section{PROJECT DESCRIPION}

Absumha service allows the customer to use the POS network with the ATM card and the fingerprint. Therefore; it requests from the customer to enter PIN number and his/her fingerprint to be placed on a
Fingerprint reader. The fingerprint reader accepts the fingerprint and seeks to match the live sample with the already registered templates in the banks database. When the fingerprint is found correct, the customer will be able to do the required payment, otherwise the customer is denied access. The system also allows the customer to use more than one account in several banks so that he chooses the bank that he/she wants to withdraw the amount from it. The service will provide security, privacy and ease of use for the customer. The bank will also benefit from fees for financial transactions as well as maintenance, installation and replacement fees. The Saudi Payments Network will receive a portion of the fees. The benefit will also count merchants as it will reduce the problems they face in paying, procrastination and the delay of payments.

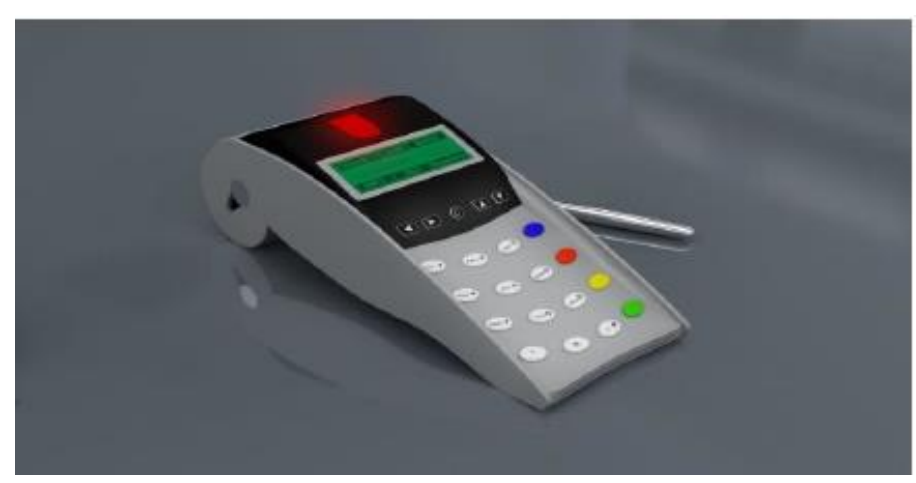

Figure 1 : The proposed POS with Embedded

Fingerprint Biometric Authentication.

The POS device consists of physical parts as shown in figure 1, a scanner that reads the customer's fingerprint, a screen showing all the customer's data including the account number and the amount to be deducted, cards and a receipt, a keyboard containing the numbers and button of entry and withdrawal, as well as confirm and correct the operation and the port of the card. Also, the logo of absumha project was designed as shown in Figure 2. 


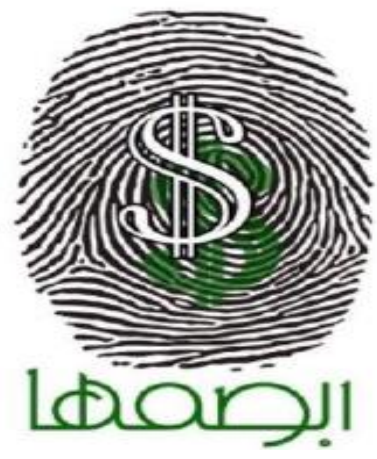

Figure 2 : The proposed logo for the project

\section{FEASIBILITY STUDY}

For market study, a questionnaire consisting of 16 questions was presented. The number of males who answered the questionnaire was 159 and the number of females was 427 . In response to the questionnaire, the market need was derived from the use of the fingerprint POS network. The majority of 198 respondents responded to the need for a fingerprint system, while those who preferred ATM cards numbered 69, while those who did not mind using both methods were 319. Moreover, the results of the questionnaire revealed that there are many drawbacks faced by people using ATM cards such as the expiration of the card, forgetting and losing the card as well. The majority of respondents believed that the fingerprint system would reduce theft and counterfeiting, and the majority expressed their desire to document their register with the banks if the idea was applied. Respondents also said that the fingerprint system would save a lot of time as well as facilitate their payments.

\subsection{Marketing study}

\subsubsection{Product Description}

Absumha service allows the customer to use the POS network with the ATM card and the fingerprint. The idea is to put the customer finger in the fingerprint reader in the POS network, where the customer's fingerprint is linked to his bank account in advance. The system also allows the customer to use more than one account in several banks so that he chooses the bank to deduct the amount of the process through. The POS network is small in size and easy to use and provided by banks, and the people who will get benefit from it are customers, banks and traders. The service will provide security, privacy and ease of use for the customer. The bank will also benefit from fees for financial transactions as well as maintenance, installation and replacement fees. The Saudi Payments Network will receive a portion of the fees.

\subsubsection{Market Description}

Market segmentation aims at dividing the market into homogeneous sectors with each sector being viewed as a marketing objective by creating an appropriate marketing mix for each category. Absumha service will be based on financial services. On the basis of this, the financial market will be divided into individuals and companies, where the focus will be on the business sector, which is divided into small, medium and large companies. In addition, the market for which we will provide this service is a competitive market where there are many competitors who are developing services rapidly as Atheer service provided by most banks which is one of the most competitors that has developed the POS network service. Table 1 below shows the characteristics of the target sector, where the service of the company focuses on the business sector of all sizes. 
Table 1 : illustrates the characteristics of the target sector

\begin{tabular}{|c|c|c|c|}
\hline Comparison criteria & Small Companies & Medium Companies & Large Companies \\
\hline $\begin{array}{c}\text { Independence of the Board of } \\
\text { Directors }\end{array}$ & N/A & $\begin{array}{c}\text { More independent than } \\
\text { small }\end{array}$ & Full independence \\
\hline Use of technology & Simple technology & $\begin{array}{c}\text { More sophisticated } \\
\text { technology }\end{array}$ & Advanced technology \\
\hline Number of employees & Few & Medium & Large \\
\hline Ability to innovate & Low & Medium & High \\
\hline Capital size & Low (high fluidity) & Medium & Large \\
\hline Need for funding & More savings and & The correlation between \\
\hline less investment & savings and investment & Less savings and \\
more investment
\end{tabular}

The questionnaire clearly shows the need to activate the service of the fingerprint and make sure that there is an alternative to the ATM card because of the many problems that accompany it. Table 2 shows the number of transactions in the period from 2013 to
2017, the table shows that POS operations are increasing from year to year, indicating that the fingerprint system will be very popular with customers in the future.

Table 2 : shows the number of transactions using POS network

\begin{tabular}{|c|c|c|c|}
\hline Period & Sales (in 1000 SR) & Period & Number of POS devices \\
\hline 2013 & $134,194,183$ & $265,315,873$ & 107,763 \\
\hline 2014 & $159,970,264$ & $327,034,423$ & 138,779 \\
\hline 2015 & $172,835,453$ & $394,915,865$ & 225,372 \\
\hline 2016 & $182,748,679$ & $524,569,736$ & 267,827 \\
\hline 2017 & $200,467,827$ & $708,119,092$ & 299,942 \\
\hline
\end{tabular}


One of the factors influencing the demand is the fear of using modern technical means. Therefore, it may not be available in all shops, and the demand at the beginning of the fingerprint service will be few. So Absumha will be announced through an explanatory video of the service in the social network.

\section{Packaging:}

The packaging of the POS machine is shown in figure 3 which includes:

\section{POS device}

2. The seller's card uses for refunds

3. Charger and base

4. Printing paper receipt.

5. A publication for customers clarifying the service.

6. Cable for charging and internet connection.

7. Fingerprint scanner.

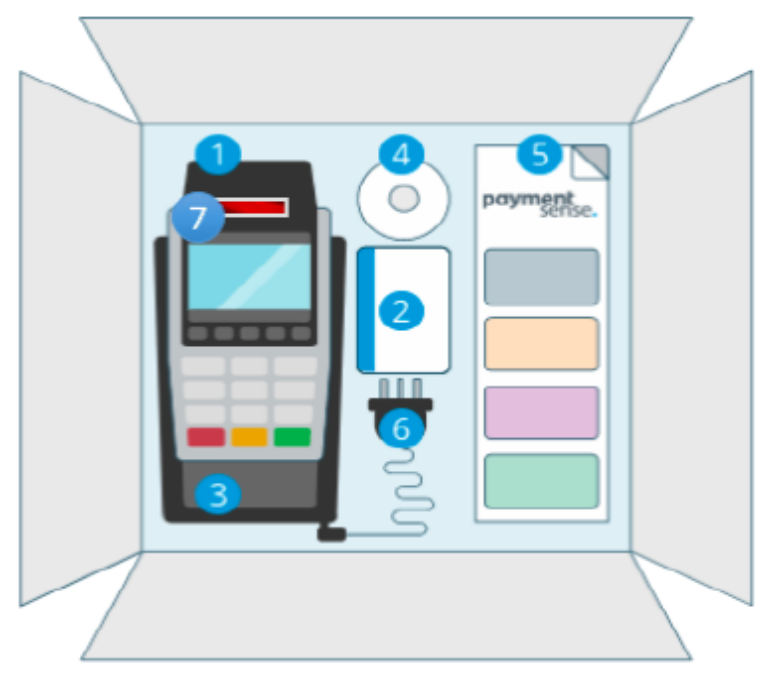

Figure 3 : Shows the method of packaging

Demand will be predicted by descriptive prediction, due to lack of historical data on demand. This prediction will be medium-term since it will provide a new service and add on the current POS network device. The survey also revealed that the total numbers of customers who wish to add a fingerprint in the POS network are $79.2 \%$ from 591 people; this indicates customer desire for this new service.

\subsubsection{Marketing Mix}

\section{- Banking Service}

The fingerprint service has been introduced using the POS network, which aims to satisfy customers' need for a secure alternative. It provides time and effort besides the ATM card, where the customer is considered the cornerstone of service delivery. Currently, there are some alternatives that may affect the fingerprint service using the POS network such as Atheer, ATM and apple pays. However, after conducting a market study, customers are faced by problems with using an ATM card, losing or falsifying it, and fingerprint service is characterized by high security.

\section{- Pricing of Banking Services}

If the idea is sold to the banks, the price will be five hundred thousand Saudi Riyals based on the value invested from the production stage to the stage of developing the marketing strategies used. On the other hand, if the fingerprint using the POS network device is sold, the cost is estimated at SR 5,000 plus a profit margin of $2.5 \%$, through the view of some sites in addition to communication with the Saudi banks to know the final cost. POS networks will be distributed through the bank to merchants or customers via direct distribution.

\section{- Promotion of banking services}

The bank advertising is one of the means of promotion that will be used to promote Absumha service, which aims to deliver all information related to the service to customers. The advertisement will clarify the shape of the device and what are the fingerprint service using POS networks and its features. Table 3 shows the cost of promoting Absumha service. 
Table 3 : The cost of promoting Absumha service

\begin{tabular}{|c|c|c|}
\hline Type & Cost/Percentage & Details of numbers \\
\hline Cost & SR 5,000 & $\begin{array}{c}\text { The cost is estimated at } 5000 \text {, depending on the contact } \\
\text { with the official at the Saudi Investment Bank and with } \\
\text { the suppliers. }\end{array}$ \\
\hline Revenue & $\begin{array}{c}\text { The revenue on the single } \\
\text { transaction through the ATM card } \\
\text { is } 0.8 \% \text {, while the revenue per } \\
\text { transaction through the fingerprint } \\
\text { is } 0.95 \% \text {, and the revenue per } \\
\text { transaction through the credit card } \\
\text { is } 2.5 \% \text {. }\end{array}$ & $\begin{array}{c}\text { Revenue is obtained through the number of } \\
\text { transactions. The bank takes } 0.8 \% \text { of the transaction } \\
\text { through the ATM card and takes } 2.5 \% \text { on the one } \\
\text { transaction through the credit card. }\end{array}$ \\
\hline $\begin{array}{c}\text { Profit } \\
\text { margin }\end{array}$ & $2.5 \%$ & $\begin{array}{c}\text { The profit margin was estimated at } 2.5 \% \text { because of } \\
\text { competition in the banking sector. Traders prefer to get } \\
\text { the device at a lower cost. }\end{array}$ \\
\hline $\begin{array}{c}\text { Cost of } \\
\text { promotion }\end{array}$ & SR 30,400 & $\begin{array}{c}\text { The cost of the video is estimated at } 6000 \text { riyals based } \\
\text { on the video designer, and 4000 riyals on advertising in } \\
\text { social media such as Twitter, Instagram and Snape } \\
\text { Chat according to the number of times it appeared in } \\
\text { the advertisement. SR } 20400 \text { is the cost of the } \\
\text { publications is in the branches of the bank, indicating } \\
\text { its service to the customers, based on communication } \\
\text { with the Sahara Advertising Agency for advertising } \\
\text { services. }\end{array}$ \\
\hline
\end{tabular}

\section{- Design Distribution Structure}

Absumha service will be distributed through the bank to merchants or customers, which means direct distribution policy will be followed. The service will cover most of the shops, where the distribution policy will be used through the wider presentation of the service through a simple and comprehensive advertising of the idea to be clear, and to become accessible to the largest possible number of beneficiaries. This is through the offer of banks to it, where the bank to submit and offer to the Saudi Arabian Monetary Agency to apply as an addition to the POS network and Sama apply the idea effectively and distribute to the banks that request it.

\subsection{Technical study}

Technical feasibility study is one of the cornerstones of the feasibility study. Technical feasibility study leads to the clarity the technical aspects of the fingerprint service bt POS network. Technical feasibility study depends on the results obtained from the marketing study. We will mention location of the service, machinery and equipment required for the service, identification of the required production elements and identification of the requirements and other services required by the service will be addressed.

\subsubsection{Locate the service}

It is the responsibility of the Bank to choose the appropriate location to provide fingerprint service by the POS network, and must be close to the target groups.

\subsubsection{Determining the service area}

The project does not need to allocate land or space to its own production unit, because the suppliers will be dependent on the manufacturer of the device with its own specifications.

Fingerprint with POS network will include 3 parts:

1. The final form which requires an indication of how the project will be presented.

2. Mechanism of work, which shows how the POS machine works using the fingerprint.

3. After-sale services.

\subsubsection{Machinery and equipment for service}

This service depends on the computer hardware to have the necessary software and databases. The costumer has to submit his fingerprint to be certified in case he wants to make payments with his fingerprint as a second option to the card. When the customer wants to make payments through the POS network using the fingerprint, the machine shows him all the banks accounts and he has to selects one of them.

- Tools used:

[1]. Network payment system.

[2]. Charge coupled device. 
- Programs used:

Saudi Payments Network (SPAN): Connects ATMs and POS networks throughout the Kingdom of Saudi Arabia with a central network. Some bank programs are confidential so they cannot be compromised. Table 4 provides description of the tools necessary to the service to work properly.

Table 4 : Description of the tools necessary for the service

\begin{tabular}{|c|c|}
\hline Tools & Description \\
\hline Device shape & $\begin{array}{l}\text { It is a device that provides service } \\
\text { with an ATM card port and a } \\
\text { fingerprint scanner and contains } \\
\text { several buttons. }\end{array}$ \\
\hline $\begin{array}{l}\text { System to link } \\
\text { client accounts }\end{array}$ & $\begin{array}{l}\text { It is a system that shows the } \\
\text { coaster accounts if he chooses the } \\
\text { payment system by footprint }\end{array}$ \\
\hline Port card & $\begin{array}{l}\text { It is a special port for the card that } \\
\text { the machine can read to be drawn } \\
\text { from }\end{array}$ \\
\hline $\begin{array}{l}\text { Saudi } \\
\text { Payments } \\
\text { Network } \\
\text { (SPAN) }\end{array}$ & $\begin{array}{l}\text { It works to connect the device } \\
\text { with a POS network all over Saudi } \\
\text { Arabia with a central network. }\end{array}$ \\
\hline $\begin{array}{l}\text { charge device } \\
\text { coupled }\end{array}$ & $\begin{array}{l}\text { It is a matrix of light-sensitive } \\
\text { cells that produces a light when } \\
\text { exposed to a digital cycle } \\
\text { electronically recorded, when the } \\
\text { customer puts his finger on the } \\
\text { device to identify the client's } \\
\text { accounts. }\end{array}$ \\
\hline $\begin{array}{l}\text { Other } \\
\text { programs }\end{array}$ & $\begin{array}{l}\text { Bank programs are confidential, so } \\
\text { they are not hacked. }\end{array}$ \\
\hline
\end{tabular}

\subsubsection{Production elements}

This service requires many elements of production and other inputs to be finished in final form and the project requires tangible part which will be made by mada machines or from external industries. We make the design as described in the product description to suit the model to be done.

\section{- Permits}

Point-of-sale services were introduced in 1990 in Saudi Arabia. Customers are provided with point-ofsale terminals through banks through the Merchant Agreement System (MSP). The Saudi Arabian Monetary Agency (SAMA) has also provided a pointof-sale engineer in each bank.

Banks and POS suppliers such as JEDIA should follow up the licenses issued by the Saudi Arabian Monetary Agency (SAMA). SAMA Department of Quality Assurance and Quality Assurance ensures the integrity of the purchasing process carried out through POS networks using the fingerprint, and technical testing is required to ensure that point-ofsale devices comply with international standards such as the EMVco standard.

\section{- Disclosure rules}

Trader Bank shall have access to all information related to the transactions made through the service, for the purpose of verifying the banking authorities (SAMA) on the operation process and the merchant's should accept this.

\section{- Protection}

Trader shall bear all costs and damages that may be incurred by the Bank as a result of negligence or misconduct of the Trader in connection with the transactions performed through service. In addition, the Bank is entitled to immediately suspend the Service from the Authority permanently or temporarily or to reserve any amount in the Trader's accounts until the damage and potential losses have been determined. 


\section{- Statements and Guarantees}

The Bank and the merchant shall acknowledge and guarantee the following:

[1]. The merchant has full authority to sign the agreement on the networks of POS and to fulfill the obligations contained therein.

[2]. The dealer signing the agreement of the POS network will not conflict with SAMA documents.

[3]. The trader must, at the time of signature of the agreement, continue to apply it throughout the contract period in accordance with applicable regulations.

\section{- Marketing services}

a. The promotion of the service will be through a video graphic that explains the service to customers.

b. Publication of the advertisement in the social media such as Twitter, Instagram and Snapchat.

c. Publications in the branches of the bank to show the service for customers.

\subsection{Financing Study}

\subsubsection{Net present value}

- The initial capital cost is SR 5000 after contacting the suppliers. This cost was calculated after adding the fingerprint to the POS network.

- Cash flow (annual revenue on transactions to be performed by merchant customers):

1. Revenue on ATM card (2.5\%)

2. Revenue on Visa and Mastercard (2.5\%)

3. Revenue on fingerprint $(0.95 \%)$

Where the previous percentages (ATM, Visa and Mastercard) are reached from the banks, and as for the fingerprint, it is reached according to the Bank's desire to make profit. The revenue for the first six years of the project will be calculated below:

\section{- $\quad$ First Year 2020}

The number of operations was forecasted based on previous data released by the Saudi Arabian Monetary Agency and showing the number of previous POS transactions in the Kingdom of Saudi Arabia as a whole. Hence, the last year 2019-2018 was based on the forecast for 2020, which was estimated by researchers as a new addition to the POS system. So, the researcher agreed on $4.25 \%$ in the first year.

\section{- Calculation of Initial Investment Cost}

As for the cost of the initial investment after we contacted several banks on the number of devices to be produced in the first year, especially as it is a new idea, Therefore, the Bank decided to contact the suppliers to request 10 thousand devices in the first year, where the initial investment cost is 50 million Saudi Riyals. And the result is that when the launch of any new project accompanied by apprehension by customers, initially the sales was expected about 10,000 thousand devices in the first year, that is, the initial investment cost for the first year:

$10000 \times 5000=50$ million

According to preliminary calculations, the revenues obtained through the Absumha service for the next six years will cover the costs incurred. This shows that the investment is feasible and successful, and that the implementation of this project will generate profits.

\section{v. CONCLUISON}

In this paper, an embedded fingerprint biometric authentication scheme for Point of Sale (POS) network as additional security option to the ATM 
card was proposed. A fingerprint biometric technique was fused with personal identification numbers (PIN's) for authentication to upgrade the security level. The results of the study show the importance of having an additional substitute for the ATM card when dealing with the POS check. We conducted a feasibility study including marketing, technical and financial study, as well as analysis of time, cost, risks and expected problems. This service facilitates the customer to conduct daily transactions through the existence of an alternative to secure the card, and based on the results of the questionnaire, which showed the need of customers to have a safe alternative to the card and high support for the idea is expected as it will reduce the problems related to the ATM cards.

\section{REFERENCES}

[1]. J. O. Adeoti, "Automated teller machine (ATM) frauds in Nigeria: The way out," Journal of Social Sciences, vol. 27, pp. 53-58, 2011.

[2]. P. A. Ochang and P. O. Ofem, "An Enhanced Automated Teller Machine Security Prototype using Fingerprint Biometric Authentication," International Journal of Advanced Networking and Applications, vol. 8, p. 3110, 2017.

[3]. F. S. Hossian, A. Nawaz, and K. Grihan, "Biometric authentication scheme for ATM banking system using energy efficient AES processor," International Journal of Information and Computer Science, vol. 2, pp. 57-63, 2013.

[4]. J. B. Awotunde, T. R. James, S. I. Abdulkadir, and F. T. Adewunmi-Owolabi, "Fingerprint Authentication System: Toward Enhancing ATM Security," 2014.

[5]. M. Dutta, K. K. Psyche, and S. Yasmin, "ATM transaction security using fingerprint recognition," Am J Eng Res (AJER), vol. 6, pp. 2320-0847, 2017.
[6]. K. R. Khatmode Ranjit, Ghodke Bharat ,P.P.Chitte,Anap S.D, "ARM7 Based Smart ATM Access \& Security System Using Fingerprint Recognition \& GSM Technology," International Journal of Emerging Technology and Advanced Engineering, vol. 4, pp. 856-860, 2014.

[7]. V. Padmapriya and S. Prakasam, "Enhancing ATM security using fingerprint and GSM technology," International Journal of Computer Applications, vol. 80, 2013.

[8]. A. Jaiswal and M. Bartere, "Enhancing ATM Security Using Fingerprint and GSM Technology," International Journal of Computing Science and Mobile Computing (IJCSM), vol. 3, 2014.

[9]. M. O. Onyesolu and I. M. Ezeani, "ATM security using fingerprint biometric identifer: An investigative study," International Journal of Advanced Computer Science and Applications, vol. 3, pp. 68-72, 2012.

[10]. S. S. Ghodke, H. Kolhe, S. Chaudhari, K. Deshpande, and S. Athavle, "ATM transaction security system using biometric palm print recognition and transaction confirmation system," International Journal Of Engineering And Computer Science, vol. 3, pp. 5332-5335, 2014

[11]. M. k. Alsmadi, K. B. Omar, S. A. Noah, and I. Almarashdah, "Performance Comparison of Multi-layer Perceptron (Back Propagation, Delta Rule and Perceptron) algorithms in Neural Networks," in 2009 IEEE International Advance Computing Conference, 2009, pp. 296-299.

[12]. Z. Thalji and M. Alsmadi, "Iris Recognition using robust algorithm for eyelid, eyelash and shadow avoiding," World Applied Sciences Journal, vol. 25, pp. 858-865, 2013. 
[13]. M. Alsmadi, U. A. Badawi, and H. E. Reffat, "A High Performance Protocol for Fault Tolerant Distributed Shared Memory (FaTP)," Journal of Applied Sciences, vol. 13, pp. 790-799, 2013.

[14]. F. HADDAD, J. ALFARO, and M. K. ALSMADI, "HOTELLING'S T² CHARTS USING WINSORIZED MODIFIED ONE STEP M-ESTIMATOR FOR INDIVIDUAL NON NORMAL DATA," Journal of Theoretical \& Applied Information Technology, vol. 72, pp. 215-226, 2015.

[15]. F. Haddad and M. K. Alsmadi, "Improvement of The Hotelling's T2 Charts Using Robust Location Winsorized One Step M-Estimator (WMOM)," Journal of Mathematics (ISSN 1016-2526), vol. 50, pp. 97-112, 2018.

[16]. M. K. Alsmadi, U. A. Badawi, and H. M. Moharram, "SERVER FAILURES ENABLED JAVASPACES SERVICE," Journal of Computer Science, vol. 10, pp. 671-679, 2014.

[17]. M. K. Alsmadi, "Apparatus and method for lesions segmentation," ed: US Patent App. 15/614,893, 2018.

[18]. M. K. Alsmadi, "Facial expression recognition," ed: Google Patents, 2018.

[19]. R. Aldaej, L. Alfowzan, R. Alhashem, M. K. Alsmadi, I. Al-Marashdeh, U. A. Badawi, M. Alshabanah, D. Alrajhi, and M. Tayfour, "Analyzing, Designing and Implementing a Web-Based Auction online System," International Journal of Applied Engineering Research, vol. 13, pp. 8005-8013, 2018.

[20]. H. Almaimoni, N. Altuwaijri, F. Asiry, S. Aldossary, M. Alsmadi, I. Al-Marashdeh, U. A. Badawi, M. Alshabanah, and D. Alrajhi, "Developing and Implementing WEB-based Online Destination Information Management System for Tourism," International Journal of Applied Engineering Research, vol. 13, pp. 7541-7550, 2018.
[21]. I. A. Almrashdeh, N. Sahari, N. A. M. Zin, and M. Alsmadi, "Requirement analysis for distance learning management system students in Malaysian universities," Journal of Theoretical and Applied Information Technology, vol. 24, pp. 17-27, 2011.

[22]. M. k. Alsmadi, K. B. Omar, and S. A. Noah, "Proposed method to decide the appropriate feature set for fish classification tasks using Artificial Neural Network and Decision Tree," IJCSNS vol. 9, pp. 297-301, 2009.

[23]. N. Alsubaie, N. Althaqafi, E. Alradwan, F. AlHazza, M. Alsmadi, I. Al-Marashdeh, U. A. Badawi, M. Alshabanah, D. Alrajhi, S. Alsmadi, and M. Tayfour, "Analyzing and Implementing an Online Metro Reservation System," International Journal of Applied Engineering Research, vol. 13, pp. 9198-9206, 2018.

[24]. D. A. Daniyah Alkhaldi, Hajer Aldossary, Mutasem k. Alsmadi, Ibrahim Al-Marashdeh, Usama A Badawi, Muneerah Alshabanah, Daniah Alrajhi, "Developing and Implementing Web-based Online University Facilities Reservation System," International Journal of Applied Engineering Research, vol. 13, pp. 6700-6708, 2018.

[25]. i. Almarashdeh, M. K. Alsmadi, T. Farag, A. S. Albahussain, U. A. Badawi, N. Altuwaijri, H. Almaimoni, F. Asiry, S. Alowaid, M. Alshabanah, D. Alrajhi, A. A. Fraihet, and G. Jaradat, "Real-Time Elderly Healthcare Monitoring Expert System Using Wireless Sensor Network " International Journal of Applied Engineering Research, vol. 13, pp. 3517-3523, 2018.

[26]. M. K. S. Al Smadi, "Fish Classification Using Perceptron Neural Network," Centre for Graduate Studies, Universiti Utara Malaysia, 2007. 
[27]. M. K. Alsmadi and U. A. Badawi, "Pattern matching in Rotated Images Using Genetic Algorithm," Journal of King Abdulaziz University Computing and Information vol. 5, pp. 53 - 59, 2017.

[28]. S. Aldossary, A. Althawadi, M. Almotairy, M. k. Alsmadi, D. Alrajhi, M. Alshabanah, I. AlMarashdeh, M. Tayfour, and R. Aljamaeen, "ANALYZING, DESIGNING

AND IMPLEMENTING A WEB-BASED COMMAND CENTER SYSTEM," International Research Journal of Engineering and Technology, vol. 6, pp. 1008-1019, 2019.

[29]. R. A. Sheikh, R. Al-Assami, M. Albahr, M. A. Suhaibani, M. k. Alsmadi, M. Alshabanah, D. Alrajhi, I. Al-Marashdeh, S. Alsmadi, H. Abouelmagd, and M. Tayfour, "Developing and Implementing a Barcode Based Student Attendance System," International Research Journal of Engineering and Technology, vol. 6, pp. 497-506, 2019.

[30]. S. A. S. Ali, K. E. H. I. Eldaw, M. K. Alsmadi, and I. Almarashdeh, "Determinants of deposit of commercial banks in Sudan: an empirical investigation (1970-2012)," International Journal of Electronic Finance, vol. 9, pp. 230255, 2019.

[31]. L. Eljawad, R. Aljamaeen, M. K. Alsmadi, I. AlMarashdeh, H. Abouelmagd, S. Alsmadi, F. Haddad, R. A. Alkhasawneh, M. Alzughoul, and M. B. Alazzam, "Arabic Voice Recognition Using Fuzzy Logic and Neural Network," International Journal of Applied Engineering Research, vol. 14, pp. 651-662, 2019.

[32]. M. K. Alsmadi, M. Tayfour, R. A. Alkhasawneh, U. Badawi, I. Almarashdeh, and F. Haddad, "Robust feature extraction methods for general fish classification," International Journal of Electrical \& Computer Engineering (20888708), vol. 9, 2019.
[33]. F. Haddad, M. K. Alsmadi, U. Badawi, T. Farag, R. Alkhasawneh, I. Almarashdeh, and W. Hassan, "Bivariate modified hotelling's $\mathrm{T}^{2}$ charts using bootstrap data," International Journal of Electrical \& Computer Engineering (2088-8708), vol. 9, 2019.

[34]. A. M. Al-Smadi, M. K. Alsmadi, A. Baareh, I. Almarashdeh, H. Abouelmagd, and O. S. S. Ahmed, "Emergent situations for smart cities: a survey," International Journal of Electrical \& Computer Engineering (2088-8708), vol. 9, 2019.

[35]. R. Al-Theeb, H. Al-Tami, H. Al-Johani, A. AlMutairi, I. Al-Marashdeh, M. K. Alsmadi, M. Alshabanah, and D. Alrajhi, "Developing and Implementing A System for Shipping Companies Comparison," IJSRST vol. 6, 2019.

[36]. I. Almarashdeh, G. Jaradat, A. Abuhamdah, M. Alsmadi, M. B. Alazzam, R. Alkhasawneh, and I. Awawdeh, "The Difference Between Shopping Online Using Mobile Apps and Website Shopping: A Case Study of Service Convenience."

[37]. M. K. Alsmadi, "Query-sensitive similarity measure for content-based image retrieval using meta-heuristic algorithm," Journal of King Saud University-Computer and Information Sciences, vol. 30, pp. 373-381, 2018.

[38]. I. Almarashdeh, K. E. Eldaw, M. AlSmadi, U. Badawi, F. Haddad, O. A. Abdelkader, G. Jaradat, A. Alkhaldi, and Y. Qawqzeh, "Search Convenience and Access Convenience: The Difference Between Website Shopping and Mobile Shopping," in International Conference on Soft Computing and Pattern Recognition, 2018, pp. 33-42.

[39]. M. Alsmadi, "Facial recognition under expression variations," Int. Arab J. Inf. Technol., vol. 13, pp. 133-141, 2016. 
[40]. M. K. Alsmadi, "Forecasting River Flow in the USA Using a Hybrid Metaheuristic Algorithm with Back-Propagation Algorithm," Scientific Journal of King Faisal University (Basic and Applied Sciences), vol. 18, pp. 13-24, 2017.

[41]. G. M. Jaradat, A. Al-Badareen, M. Ayob, M. AlSmadi, I. Al-Marashdeh, M. Ash-Shuqran, and E. Al-Odat, "Hybrid Elitist-Ant System for Nurse-Rostering Problem," Journal of King Saud University-Computer and Information Sciences, 2018.

[42]. T. H. Farag, W. A. Hassan, H. A. Ayad, A. S. AlBahussain, U. A. Badawi, and M. K. Alsmadi, "Extended Absolute Fuzzy Connectedness Segmentation Algorithm Utilizing Region and Boundary-Based Information," Arabian Journal for Science and Engineering, pp. 1-11, 2017.

[43]. M. Alsmadi, K. Omar, S. Noah, I. Almarashdeh, S. Al-Omari, P. Sumari, S. Al-Taweel, A. Husain, N. Al-Milli, and M. Alsmadi, "Fish recognition based on robust features extraction from size and shape measurements using neural network," Information Technology Journal, vol. 10, pp. 427-434, 2009.

[44]. R. Al-Theeb, H. Al-Tami, H. Al-Johani, A. AlMutairi, I. Almarashdeh, M. Alsmadi, M. Alshabanah, and D. Alrajhi, "Developing and Implementing A System for Shipping Companies Comparison," AL-THEEB, R., ALTAMI, H., AL-JOHANI, H., AL-MUTAIRI, A., AL-MARASHDEH, I., ALSMADI, MK, ALSHABANAH, M. \& ALRAJHI, D, 2019.

[45]. E. Alomari, M. Alshammry, S. Alhamil, M. Alsmadi, M. Alshabanah, D. Alrajhi, I. Almarashdeh, and L. Eljawad, "Analyzing, Designing and Implementing a Consulting Company for Management Information Systems," ALOMARI, E., ALSHAMMRY, M., ALHAMIL, S., ALSMADI, MK, ALSHABANAH, M., ALRAJHI, D.,
ALMARASHDEH, I. \& ELJAWAD, L, pp. 422432, 2019.

[46]. M. khalil Alsmadi, K. B. Omar, S. A. Noah, and I. Almarashdah, "Performance comparison of multi-layer perceptron (Back Propagation, Delta Rule and Perceptron) algorithms in neural networks," in 2009 IEEE International Advance Computing Conference, 2009, pp. 296-299.

[47]. A. M. Al Smadi, M. K. Alsmadi, H. Al Bazar, S. Alrashed, and B. S. Al Smadi, "Accessing Social Network Sites Using Work Smartphone for Face Recognition and Authentication," Research Journal of Applied Sciences, Engineering and Technology, vol. 11, pp. 5662, 2015.

[48]. M. Alsmadi, K. Omar, and I. Almarashdeh, Fish Classification: Fish Classification Using Memetic Algorithms with Back Propagation Classifier: LAP LAMBERT Academic Publishing, 2012.

[49]. M. Alsmadi, K. Omar, S. Noah, and I. Almarashdeh, "A hybrid memetic algorithm with back-propagation classifier for fish classification based on robust features extraction from PLGF and shape measurements," Information Technology Journal, vol. 10, pp. 944-954, 2011.

[50]. M. Alsmadi, K. B. Omar, S. A. Noah, and I. Almarashdeh, "Fish Recognition Based on Robust Features Extraction from Size and Shape Measurements Using Neural Network " Journal of Computer Science, vol. 6, pp. 1088-1094, 2010.

[51]. M. K. Alsmadi, "An efficient similarity measure for content based image retrieval using memetic algorithm," Egyptian Journal of Basic and Applied Sciences.

[52]. M. K. Alsmadi, "Query-sensitive similarity measure for content-based image retrieval 
using meta-heuristic algorithm," Journal of King Saud University - Computer and Information Sciences.

[53]. M. K. Alsmadi, A. Y. Hamed, U. A. Badawi, I. Almarashdeh, A. Salah, T. H. Farag, W. Hassan, G. Jaradat, Y. M. Alomari, and H. M. Alsmadi, "FACE IMAGE RECOGNITION BASED ON PARTIAL FACE MATCHING USING GENETIC ALGORITHM," SUST Journal of Engineering and Computer Sciences (JECS), vol. 18, pp. 51-61, 2017.

[54]. M. K. Alsmadi, K. B. Omar, S. A. Noah, and I. Almarashdeh, "Fish recognition based on robust features extraction from color texture measurements using back-propagation classifier," Journal of Theoritical and Applied Information Technology, vol. 18, 2010.

[55]. U. A. Badawi and M. K. Alsmadi, "A GENERAL FISH CLASSIFICATION METHODOLOGY USING META-HEURISTIC ALGORITHM WITH BACK PROPAGATION CLASSIFIER," Journal of Theoretical \& Applied Information Technology, vol. 66, pp. 803-812, 2014.

[56]. M. Yousuf, Z. Mehmood, H. A. Habib, T. Mahmood, T. Saba, A. Rehman, and M. Rashid, "A Novel Technique Based on Visual Words Fusion Analysis of Sparse Features for Effective Content-Based Image Retrieval," Mathematical Problems in Engineering, vol. 2018, 2018.

[57]. R. R. Saritha, V. Paul, and P. G. Kumar, "Content based image retrieval using deep learning process," Cluster Computing, pp. 1-14, 2018.

[58]. M. K. Alsmadi, K. B. Omar, and S. A. Noah, "Fish recognition based on robust features extraction from size and shape measurements using back-propagation classifier," International Review on Computers and Software, vol. 5, pp. 489-494, 2010.
[59]. M. K. Alsmadi, K. B. Omar, S. A. Noah, and I. Almarashdeh, "Fish recognition based on robust features extraction from size and shape measurements using neural network," Journal of Computer Science, vol. 6, p. 1088, 2010.

[60]. M. K. S. Alsmadi, K. B. Omar, S. A. Noah, and I. Almarashdah, "Fish recognition based on the combination between robust feature selection, image segmentation and geometrical parameter techniques using Artificial Neural Network and Decision Tree," arXiv preprint arXiv:0912.0986, 2009.

[61]. M. Alsmadi, K. B. Omar, and S. A. Noah, "Back propagation algorithm: the best algorithm among the multi-layer perceptron algorithm," International Journal of Computer Science and Network Security, vol. 9, pp. 378-383, 2009.

[62]. M. K. Alsmadi, "A hybrid Fuzzy C-Means and Neutrosophic for jaw lesions segmentation," Ain Shams Engineering Journal.

[63]. U. A. Badawi and M. K. S. Alsmadi, "A Hybrid Memetic Algorithm (Genetic Algorithm and Great Deluge Local Search) With BackPropagation Classifier for Fish Recognition " International Journal of Computer Science Issues, vol. 10, pp. 348-356, 2013.

[64]. A. M, O. K, and N. S, "Back Propagation Algorithm : The Best Algorithm Among the Multi-layer Perceptron Algorithm," International Journal of Computer Science and Network Security, vol. 9, pp. 378-383, 2009.

[65]. M. Sharma, G. Purohit, and S. Mukherjee, "Information Retrieves from Brain MRI Images for Tumor Detection Using Hybrid Technique K-means and Artificial Neural Network (KMANN)," in Networking Communication and Data Knowledge Engineering, ed: Springer, 2018, pp. 145-157.

[66]. Y. Gao, X. Li, M. Dong, and H.-p. Li, "An enhanced artificial bee colony optimizer and its 
application to multi-level threshold image segmentation," Journal of Central South University, vol. 25, pp. 107-120, 2018.

[67]. M. K. Alsmadi, "A hybrid firefly algorithm with fuzzy-C mean algorithm for MRI brain segmentation," American Journal of Applied Sciences, vol. 11, pp. 1676-1691, 2014.

[68]. M. K. Alsmadi, "MRI brain segmentation using a hybrid artificial bee colony algorithm with fuzzy-c mean algorithm," Journal of Applied Sciences, vol. 15, p. 100, 2015.

[69]. M. K. Alsmadi, "A hybrid Fuzzy C-Means and Neutrosophic for jaw lesions segmentation," Ain Shams Engineering Journal, 2017.

[70]. S. H. Park and K. Han, "Methodologic Guide for Evaluating Clinical Performance and Effect of Artificial Intelligence Technology for Medical Diagnosis and Prediction," Radiology, p. 171920, 2018.

[71]. D. S. Kermany, M. Goldbaum, W. Cai, C. C. Valentim, H. Liang, S. L. Baxter, A. McKeown, G. Yang, X. Wu, and F. Yan, "Identifying Medical Diagnoses and Treatable Diseases by Image-Based Deep Learning," Cell, vol. 172, pp. 1122-1131. e9, 2018.

[72]. I. Almarashdeh, "Sharing instructors experience of learning management system: A technology perspective of user satisfaction in distance learning course," Computers in Human Behavior, vol. 63, pp. 249-255, 2016.

[73]. I. ALMARASHDEH, H. BOUZKRAOUI, A. AZOUAOUI, H. YOUSSEF, L. NIHARMINE, A. A. RAHMAN, S. S. S. YAHAYA, A. M. A. ATTA, D. A. EGBE, and B. M. MURIMO, "AN OVERVIEW OF TECHNOLOGY EVOLUTION: INVESTIGATING THE FACTORS INFLUENCING NON-BITCOINS USERS TO ADOPT BITCOINS AS ONLINE PAYMENT TRANSACTION METHOD,"
Journal of Theoretical and Applied Information Technology, vol. 96, 2018.

[74]. I. Almarashdeh, "The important of service quality and the trust in technology on users perspectives to continues use of mobile services," Journal of Theoretical \& Applied Information Technology, vol. 96, 2018.

[75]. I. Almarashdeh and M. Alsmadi, "Investigating the acceptance of technology in distance learning program," in Information Science and Communications Technologies (ICISCT), International Conference on, Tashkent Uzbekistan 2016, pp. 1-5.

[76]. I. Almarashdeh and M. Alsmadi, "Heuristic evaluation of mobile government portal services: An experts' review," in 11th International Conference for Internet Technology and Secured Transactions (ICITST), 2016, pp. 427-431.

[77]. I. Almarashdeh and M. K. Alsmadi, "How to make them use it? Citizens acceptance of Mgovernment," Applied Computing and Informatics, vol. 13, pp. 194-199, 2017/07/01/ 2017.

[78]. I. Almarashdeh and M. K. Alsmadi, "Applied Computing and Informatics," 2017.

[79]. I. Almarashdeh, A. Althunibat, and N. F. Elias, "Developing a Mobile Portal Prototype for Egovernment Services," Journal of Applied Sciences, vol. 14, pp. 791-797, 2014.

[80]. I. Almarashdeh, A. Althunibat, N. Fazidah Elias, A. Adewumi, A. Al Thunibat, N. Zin, N. Ashaari, A. Al Thunibat, N. Zin, and N. Sahari, "E-Government for mobile societiesstocktaking of current trends and initiatives," Journal of Applied Sciences, vol. 14, pp. 104111, 2013.

[81]. I. Almarashdeh, N. F. Elias, N. Sahari, and N. Zain, "Development of an interactive learning management system for malaysian distance 
learning institutions," Middle East Journal of Scientific Research, vol. 14, pp. 1471-1479, 2013.

[82]. I. AlMarashdeh, G. M. Jaradat, M. Ayob, A. Abu-Al-Aish, and M. Alsmadi, "An Elite PoolBased Big Bang-Big Crunch Metaheuristic for Data Clustering," Journal of Computer Science, 2018.

[83]. I. Almarashdeh, N. Sahari, and N. Mat Zin, "Heuristic evaluation of distance learning management system interface," presented at the International Conference on Electrical Engineering and Informatics Bandung, Indonesia 2011.

[84]. I. Almarashdeh, N. Sahari, N. M. Zin, and M. Alsmadi, "Instructors acceptance of Distance Learning Management System," in International Symposium on Information Technology 2010 (ITSim 2010), Kuala Lumpur, 2010, pp. 1-6.

[85]. I. A. Almarashdeh, N. Sahari, N. A. H. M. Zin, and M. Alsmadi, "Distance learners acceptance of learning management system," in 2nd International Conference on Data Mining and Intelligent Information Technology Applications (ICMIA2010), Seoul, Korea, 2010, pp. 304-309.

[86]. I. A. Almarashdeh, N. Sahari, N. A. H. M. Zin, and M. Alsmadi, "Distance Learning Management System requirements From Student's Perspective," The international Journal of Theoretical and Applied Information Technology, vol. 24, 2011.

[87]. I. A. Almarashdeh, N. Sahari, and N. A. M. Zin, "Heuristic evaluation of distance learning management system interface," in Electrical Engineering and Informatics (ICEEI), 2011 International Conference on, 2011, pp. 1-6.

[88]. I. A. Almarashdeh, N. Sahari, N. a. M. Zin, and M. Alsmad, "The Success of Learning
Management System Among Distance Learners in Malaysian Universitie," Journal of Theoretical and Applied Information Technology, vol. 21 pp. 80-91, 2010.

[89]. I. A. Almarashdeh, N. Sahari, N. A. M. Zin, and M. Alsmadi, "THE SUCCESS OF LEARNING MANAGEMENT SYSTEM AMONG DISTANCE LEARNERS IN MALAYSIAN UNIVERSITIES," Journal of Theoretical \& Applied Information Technology, vol. 21, 2010.

[90]. I. A. Almarashdeh, N. Sahari, N. A. M. Zin, and M. Alsmadi, "Acceptance of learning management system: A comparison between distance learners and instructors," Advances in Information Sciences and Service Sciences, vol. 3, pp. 1-9, 2011.

[91]. I. A. E. Almarashdeh, "Study of the Usability of Learning Management System Tool (Learning Care) of Postgraduate Students in University Utara Malaysia (UUM)," Graduate School, Universiti Utara Malaysia, 2007.

[92]. I. A. Almrashdah, N. Sahari, N. A. H. M. Zin, and M. Alsmadi, "Distance learners acceptance of learning management system," in Advanced Information Management and Service (IMS), 2010 6th International Conference on, 2010, pp. 304-309.

[93]. I. A. Almrashdah, N. Sahari, N. A. H. M. Zin, and M. Alsmadi, "Instructors acceptance of distance learning management system," in Information Technology (ITSim), 2010 International Symposium in, 2010, pp. 1-6.

[94]. I. A. ALMRASHDEH, N. SAHARI, N. A. M. ZIN, and M. ALSMADI, "DISTANCE LEARNING MANAGEMENT SYSTEM REQIUREMENTS FROM STUDENT'S PERSPECTIVE," Journal of Theoretical \& Applied Information Technology, vol. 24, 2011.

[95]. I. A. Almrashdeh, N. Sahari, N. A. M. Zin, and M. Alsmadi, "Instructor's success measures of 
Learning Management System," in Electrical Engineering and Informatics (ICEEI), 2011 International Conference on, 2011, pp. 1-7.

[96]. M. K. A. Ibrahim Almarashdeh, Ghaith Jaradat, Ahmad Althunibat, Sami Abdullah Albahussain, Yousef Qawqzeh, Usama A Badawi, Tamer Farag, "Looking Inside and Outside the System: Examining the Factors Influencing Distance Learners Satisfaction in Learning Management System," Journal of Computer Science, vol. 14, pp. 453-465, 2018.

[97]. G. Jaradat, M. Ayob, and I. Almarashdeh, "The effect of elite pool in hybrid population-based meta-heuristics for solving combinatorial optimization problems," Applied Soft Computing, vol. 44, pp. 45-56, 2016.

[98]. M. Rasmi, M. B. Alazzam, M. K. Alsmadi, I. A. Almarashdeh, R. A. Alkhasawneh, and S. Alsmadi, "Healthcare professionals' acceptance Electronic Health Records system: Critical literature review (Jordan case study)," International Journal of Healthcare Management, pp. 1-13, 2018.

[99]. J. Adeyemo, O. Oyebode, and D. Stretch, "River Flow Forecasting Using an Improved Artificial Neural Network," in EVOLVE-A Bridge between Probability, Set Oriented Numerics, and Evolutionary Computation VI, ed: Springer, 2018, pp. 179-193.

[100].A. Ahani, M. Shourian, and P. R. Rad, "Performance Assessment of the Linear, Nonlinear and Nonparametric Data Driven Models in River Flow Forecasting," Water Resources Management, pp. 1-17, 2018.

[101]."Global Banking \& Finance Review ${ }^{\circledR}$ is a leading financial portal and Print Magazine offering News, Analysis, Opinion, Reviews, Interviews \& Videos from the world of Banking, Finance, Business, Trading, Technology, Investing, Brokerage, Foreign
Exchange, Tax \& Legal, Islamic Finance, Asset \& Wealth Management. Copyright (C) 20102019 GBAF Publications Ltd - All Rights Reserved.."

[102].giesecke, Devrient, and bundesdruckerei, "Biometrics," Veridos, vol. https://www.veridos.com/files/assets/images/To pics\%20\&\%20Trends/Veridos\%20Biometrics\% 20White\%20Paper\%20Download.pdf, 2018.

[103].F. J. Zareen, K. A. Shakil, M. Alam, and S. Jabin, "BAMCloud: A Cloud Based Mobile Biometric Authentication Framework," arXiv preprint arXiv:1601.02781, 2016.

[104].Mada, "How mada works," https://www.mada.com.sa/en/services, 2019.

[105].TheSaudiInvestmentBank, "Mobile Point of Sales (mPOS)," https://www.saib.com.sa/en/mpos, 2019.

\section{Cite this article as :}

Hussah Adnan Alzame, Muneerah Alshabanah, Mutasem K. Alsmadi, "Point of Sale (POS) Network with Embedded Fingerprint Biometric Authentication", International Journal of Scientific Research in Science and Technology (IJSRST), Online ISSN : 2395-602X, Print ISSN : 2395-6011, Volume 6 Issue 5, pp. 95-111, September-October 2019. Available at doi https://doi.org/10.32628/IJSRST119659 Journal URL : http://ijsrst.com/IJSRST119659 